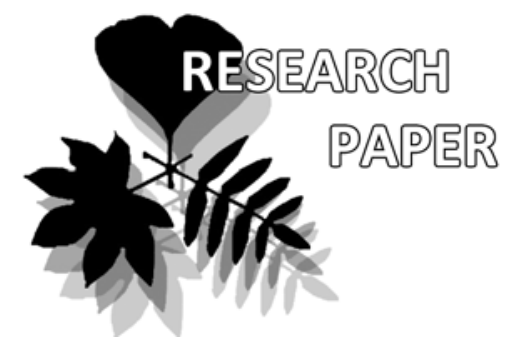

Tatiana G. Elumeeva ${ }^{1,2}$

e-mail: elumeeva@yandex.ru

Vladimir G. Onipchenko ${ }^{1}$

e-mail: vonipchenko@mail.ru

Elena N. Rovnaia ${ }^{1}$

e-mail: Elena_kuraz@mail.ru

Yan $\mathrm{Wu}^{2 *}$

e-mail:wuyan@cib.ac.cn

Marinus J. A. Werger ${ }^{3}$

e-mail: M.J.A.Werger@uu.nl

${ }^{1}$ Department of Geobotany, Biological Faculty, Moscow State Lomonosov University, Moscow, Russia

${ }^{2}$ Chengdu Institute of Biology, Chinese Academy of Sciences, Chengdu, China

${ }^{3}$ Utrecht University, Utrecht, The Netherlands

* corresponding author

Manuscript received: 28.11.2014

Review completed: 09.02.2015

Accepted for publication: 12.02.2015

Published online: 31.03.2015

\section{Alpine plant communities of Tibet and Caucasus: in quest of functional convergence}

\author{
Tatiana G. Elumeeva ${ }^{1,2}$, Vladimir G. Onipchenko ${ }^{1}$, \\ Elena N. Rovnaia ${ }^{1}$, Yan Wu ${ }^{2 *}$, Marinus J. A. Werger ${ }^{3}$
}

\begin{abstract}
A B S T R A C T
We compared aboveground phytomass structure and community weighed mean leaf traits (leaf area and specific leaf area) in alpine plant communities of Tibet (alpine shrub meadows and alpine bogs, grazed and fenced) and the Caucasus (alpine lichen heaths, Festuca varia grasslands, Geranium-Hedysarum meadows, alpine snowbeds and alpine fens). We tested, if (1) the communities at least partly show functional convergence, (2) the mean community biomass weighed traits vary in accordance with position along a catena, and (3) grazing influences community functional structure. To reveal the pattern of functional structure we run Detrended Correspondence Analysis with the biomass of functional groups as variables and plots as cases. Position along a catena was the main driver, and the alpine fens of both Tibet and the Caucasus were the most similar in functional structure. Community biomass weighed specific leaf area increased with water availability and from grass-dominated to frequently disturbed forb-dominated communities. Ke y word s : alpine vegetation, aboveground phytomass, leaf area, specific leaf area, ordination
\end{abstract}

\section{P E 3 Ю M E}

Елумеева Т.Г., Онипченко В.Г., Ровная Е.Н., У Янь, Вергер М.Аж.А. Альпийские фитоценозы Тибета и Кавказа: в поисках функционального сходства

Мы сравнили структуру надземной фитомассы и средневзвешенные по биомассе признаки Аистьев (площадь миста и удельная мистовая поверхность) в альпийских сообществах Тибета (альпийские кустарниковые муга и альпийские болота с выпасом и без) и Кавказа (альпийские Аишайниковые пустоши, пестроовсяницевые муга, гераниево-копеечниковые куга, альпийские ковры и альпийские болота). Мы проверили, 1) есть ми межАу сообществами черты функционального сходства; 2) изменяются Аи средневзвешенные признаки Аистьев в зависимости от положения сообщества в катене; 3) выпас влияет на функциональную структуру сообществ. Чтобы выявить закономерности в структуре сообществ, мы провели анализ соответствия с удаленным трендом с биомассой растений, относящихся к разным функциональным группам, в качестве зависимых переменных, и площадками в качестве независимых переменных. Положение сообщества в катене оказалось ведущим фактором, а альпийские болота Тибета и Кавказа оказались наиболее сходными по функциональной структуре. СреАневзвешенная удельная мистовая поверхность возрастала при увеличении вАажности местообитания и от сообществ с Аоминированием зАаков к сообществам с Аоминированием разнотравья и частыми нарушениями.

К $\boldsymbol{\Lambda}$ ю че в ы е с $\mathbf{\Lambda}$ ов а: альпийская растительность, надземная фитомасса, площадь Аиста, удельная Аистовая поверхность, ординация

Nome n c la t u r e : Wu \& Raven (1994-2014) - for scientific names of species from Tibet; Onipchenko et al. (2011) - for scientific names of species from Caucasus

\section{INTRODUCTION}

One of the main trends in recent vegetation studies is the analysis of the functional structure of plant communities. It is based on measurements of plant functional traits, or features which represent plant ecological strategies and determine how plants respond to environmental factors (Pérez-Harguindeguy et al. 2012).

In geographically distant regions factors constraining plant growth may lead to physiognomic similarity of communities even when species originated from different spe- cies pools but the possession of similar sets of functional traits plays a similar role in the community structure and functioning. Thus, functional traits may reflect 1) the geographical position and climatic zone in which the community thrives, 2) local peculiarities, such as position in relief, local water regime, snow cover duration, and 3) disturbance regime and land use pattern. Moreover, the same trait could be adaptive to different environmental impacts. If the leading factors affecting the community structure show similar values in distant localities, we should expect con- 
vergence in community trait performance despite different taxonomic composition. During restoration of semi-natural grasslands, community mean traits become similar, however, and species identity is not important (Helsen et al. 2012). On the other hand, physiognomically similar dry grasslands of Central Europe and the NW Balkan have significantly different community weighted mean SLA (Pipenbacher et al. 2014).

Trait data for community analysis preferably should be supplemented by plant abundance data to get community weighted trait means in order to investigate the main functional structure of communities (Cingolani et al. 2007). In this case community weighted mean traits mainly associated with dominant and subdominant species with particular traits.

Alpine vegetation develops in a harsh environment, so its structure strongly reflects both climatic effects and local peculiarities of the habitat. Furthermore, most sites within the alpine belt have been used by local people for livestock grazing, and this also influenced community structure and function. We selected alpine vegetation of two distant regions (the Northwestern Caucasus, Russia, and the eastern Qinghai-Tibetan plateau, China) to compare community phytomass structure and community biomass weighted mean traits between regions and within regions according to the position of the communities in the mesorelief. We considered two traits, which are commonly linked with climate, productivity, and grazing response: leaf area (LA) and specific leaf area (SLA). SLA reflects the plant's metabolic activity and intensity of $\mathrm{CO}_{2}$ assimilation (Schulze et al. 2005); it is correlated with the relative growth rate (Garnier 1992). Community weighted mean SLA was shown to be higher in more productive communities in Mediterranean grasslands (Chollet et al. 2014). Though these traits do not completely describe community functional structure, due to their links with other traits (Freschet et al. 2010) and environmental factors (Wright et al. 2005; Soudzilovskaia et al. 2013), the use of them allows us to explain some important patterns in vegetation.

We tested the following hypotheses: (1) the alpine communities of Tibet and the Caucasus, despite their different geographical position and floristic composition, at least partly show features of functional convergence, (2) the mean community biomass weighted traits vary in accordance with their position along a catena, and (3) grazing influences community functional structure.

\section{MATERIALS AND METHODS}

\section{Study area}

The study area in the eastern part of the Qinghai-Tibetan plateau is located at Mount Kaka (N32 ${ }^{\circ} 9^{\circ}$, E103 $\left.{ }^{\circ} 41^{\circ}\right)$, which belongs to the Minshan Mountains and lies $40 \mathrm{~km}$ northwest of Songpan County, Sichuan province, China. The timberline is at $3800-4000 \mathrm{~m}$ a.s.l.; the alpine belt is occupied by alpine meadows and shrubs. The climate of this territory typically is a mixture of the monsoon from the east and cold, dry winds from the inland plateau, and is classified as a cold summer with a dry winter (Peel et al.
2007). The annual mean temperature is $2.8^{\circ} \mathrm{C}$ with a mean values of $-7.6^{\circ} \mathrm{C}$ for January and $9.7^{\circ} \mathrm{C}$ for July. There is no absolutely frost-free season. The mean annual precipitation is $718 \mathrm{~mm}, 72 \%$ of which falls from June to August. Snow cover in the study site usually ranges from 0 to $0.4 \mathrm{~m}$ (Chen et al. 2008). The soil is a silty loam inceptisol with a $\mathrm{pH}$ of 5.54-5.94 and a SOM of $41.5-60.0 \mathrm{~g} \mathrm{~kg}^{-1} \mathrm{dry}$ soil. The studied area is mainly used as yak (Bos grunniens Linnaeus 1766) pastures.

In the alpine belt of Mt. Kaka (3930-3960 m a.s.l.) we studied two typical grazed communities with a low abundance of shrubs: alpine shrub meadows (MG, Fig. 1A) and alpine fen (FG, Fig. 1B). Alpine shrub meadows occupy the gentle southern slopes and ridges. The most abundant herbaceous species are Kobresia humilis (C.A.Mey ex. Trautv.) Serg., Sibbaldia procumbens L., Deschampsia caespitosa (L.) P. Beauv., Festuca ovina L., Polygonum macrophyllum D.Don, Thalictrum alpinum L., species of Saussurea and Gentiana. Shrubs, such as Potentilla fruticosa L. and Spiraea alpina Pallas, cover 5-10\%. A moss layer is well developed; the role of lichens is low. Alpine fens occupy smooth places at the lower parts of slopes with a high humidity. Their moss cover is about $35 \%$; the most abundant vascular plants are Carex moorcroftii Falconer ex Boott, C. muliensis Handel-Mazzetti, Kobresia humilis, K. kansuensis Kükenth., and Cremanthodium lineare Maxim. Tibetan meadows are characterized by an extremely high floristic richness (Onipchenko et al. 2014) and variety of plant life forms (Elumeeva et al. 2014).

To investigate the structure of ungrazed community in Tibet, a pasture site at $3933 \mathrm{~m}$ a.s.l. was fenced. Fencing of the alpine shrub meadow was established in July 2006 (MF, $50 \times 80 \mathrm{~m}$ ) and of the alpine fen in September 2007 (FF, $80 \times 100 \mathrm{~m})$.

The study area in the Northwestern Caucasus was located in the Teberda State Biosphere Reserve (KarachaevoCherkessian Republic, Russia). The timberline is at about $2500 \mathrm{~m}$ a.s.l. Here the alpine belt has a mountain climate of the temperate zone. The mean annual temperature is about $-1.2^{\circ} \mathrm{C}$ and the mean annual precipitation is $1400 \mathrm{~mm}$. The warmest month is August with a mean monthly temperature of $+8.3^{\circ} \mathrm{C}$, but frost can occur throughout summer (Onipchenko 2004). Grazing of the alpine communities here was ended in 1944, circa 70 years ago, and the impact of wild ungulates, such as the Caucasian ibex (Capra caucasica Guldenst.), seems to be insignificant.

Five typical alpine communities were studied: alpine lichen heath (ALH, Fig. 1C), Festuca varia grassland (FVG, Fig. 1D), Geranium-Hedysarum meadow (GHM, Fig. 1E), alpine snowbed (SBC, Fig. 1F) and alpine fen (AF). ALH occupies windward crests and slopes without snow accumulation or with a thin (up to $20-30 \mathrm{~cm}$ ) snow cover and a relatively long, ca. 5 months, growing season. The main dominants are fruticose lichens from genera Cetraria and Cladonia; the most abundant species of vascular plants are Festuca ovina L., Carex sempervirens Vill., C. umbrosa Host, Trifolium polyphyllum C.A. Mey., Anemone speciosa Adams ex Pritz., Antennaria dioica (L.) Gaertn., Campanula tridentata Schreb. The FVG occupies slopes with little snow accumulation (about 0.5-1 m), and its growing season lasts about 4 months. Dense tussock 


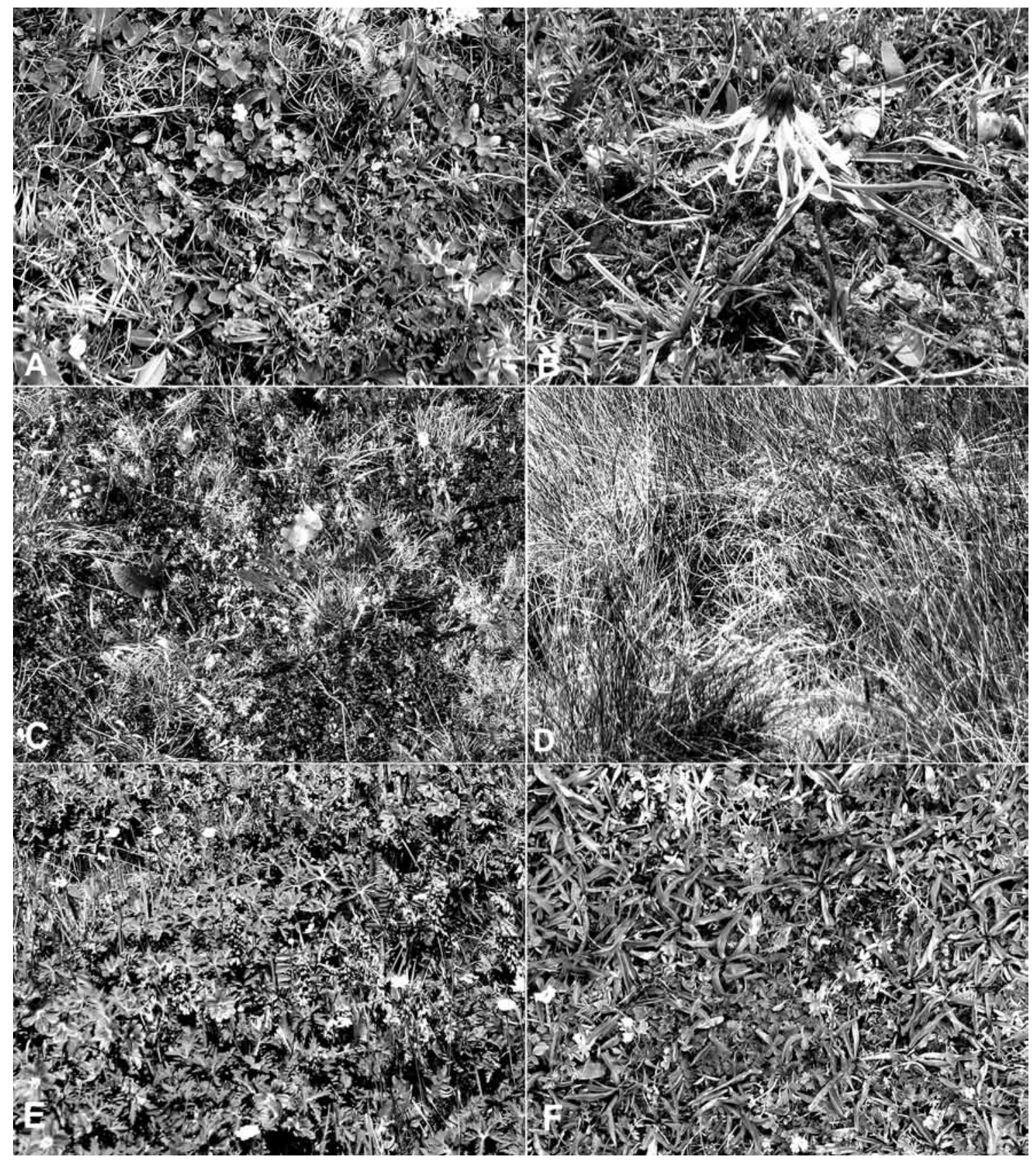

Figure 1 Plant communities studied. Tibet: A - grazed alpine meadow (MG), B - grazed alpine fen (FG) with flowering Cremanthodium lineare; the Caucasus: C - alpine lichen heath (ALH), D - Festuca varia grassland (FVG), E - Geranium-Hedysarum meadow (GHM), F - alpine snowbed (SBC). A, B, D - photos by T.G. Elumeeva. C, E, F - photos by V.G. Onipchenko

narrow-leafed grasses Festuca varia Haenke and Nardus stricta L. are the main dominants in the FVG. The GHM occurs on lower parts of slopes and in small depressions with a typical snow depth of $2-3 \mathrm{~m}$. Its growing season lasts $2.5-$ 3.5 months. The main dominants are Geranium gymnocaulon DC. and Hedysarum caucasicum M. Bieb. The SBC occupies deep depressions with a heavy winter snow accumulation of more than $4 \mathrm{~m}$. Its growing season lasts 2-2.5 months. Low stature plants, such as Sibbaldia procumbens L., Minuartia aizoides (Boiss.) Bornm., and Taraxacum stevenii DC. are the main dominants here. The AF commonly occurs along small rivers and springs and near lakes on the flat bottoms of valleys. The typical species are Carex nigra (L.) Reichard, Cirsium simplex C.A. Mey., Nardus stricta, Sibbaldia procumbens.
Few species occurs both in the Caucasian and Tibetan communities (e.g. Sibbaldia procumbens, Festuca ovina, Deschampsia caespitosa), however, the sample plots in both regions include a set of common genera (e.g. Pedicularis, Carex, Gentiana, Ranunculus, Anemone, Hedysarum and others), and the most of families are also common with the highest diversity observed in Asteraceae and Poaceae.

\section{Phytomass sampling}

We mean the term "phytomass" as a sum of living plant organs and attached litter (biomass + necromass), as it often accepted (Huck et al. 2013). The aboveground phytomass was clipped at the soil surface in square plots of $0.0625 \mathrm{~m}^{2}$ $(25 \times 25 \mathrm{~cm})$ and separated into litter, lichens, mosses and 
vascular plants by species. Plots were located in typical sites of the communities.

In Tibet the phytomass was studied during the beginning of September 2011 and in late June - July 2012. We established 57 plots in grazed alpine meadows (MG), 20 plots in grazed alpine fens (FG), 10 plots in fenced alpine meadows (MF) and 10 plots in fenced alpine fens (FF). For most of the Caucasian communities we used the database of phytomass samples collected from 1980 to 2010: 104 plots in ALH, and 92 plots in FVG, GHM and SB. The phytomass in AF was sampled in 2012-2013 and included 39 plots.

\section{Leaf traits}

In Tibet we randomly sampled 10-15 mature undamaged leaves of every species with one leaf (or 3-10 leaves for plants with small leaves) per individual (Cornelissen et al. 2003) in their typical, grazed habitats in July 2012 (Elumeeva et al. 2015). Few species were sampled also in the fenced plots. Leaves were scanned at 300 dpi resolution for large leaves and at $600 \mathrm{dpi}$ for small leaves, dried in the oven and weighted. Leaf images were processed in Corel PhotoPaint and leaf area (LA) was estimated according to number of dark pixels. Specific leaf area (SLA) was calculated by division of LA by leaf dry weight. Data on leaf traits of the Caucasian plants were taken from the existing database (Shidakov \& Onipchenko 2007).

\section{Data analysis}

For trait analysis we calculated community biomass weighted mean leaf area $\left(\mathrm{LA}_{\mathrm{CW}}\right)$ and specific leaf area $\left(\mathrm{SLA}_{\mathrm{CW}}\right)$ per plot by the formula:

$$
C_{\text {mean }}=\frac{\sum\left(m_{i} \times T r_{i}\right)}{\sum m_{i}}
$$

where $C_{\text {mean }}$ is the community weighted mean of the trait, $m$ is the biomass of species $i$ in the plot, $\operatorname{Tr}$ is the trait value for species $i, n$ is the number of species included into the analysis. The contribution of these species to the total biomass of all vascular plant species in the plots was more then $90 \%$.

To test whether the studied communities differ from each other, we run non-parametric Kruskall-Wallis ANOVA. To reveal differences between pairs of studied communities we used non-parametric Mann-Whitney U-tests. We included into the analysis the number of species per plot, total phytomass, total biomass, mass of litter, mosses, lichens and vascular plants, $\mathrm{LA}_{\mathrm{CW}}$ and SLA $\mathrm{CW}_{\mathrm{CW}}$

To reveal consistent patterns in the functional structure of the studied communities we run Detrended Correspondence Analysis (DCA) of plots in PCord 4. As the species pools of Tibet and the Caucasus include few vascular plant species common to both regions, we combined the species into the following 9 functional groups: shrubs, dwarf shrubs, annual forbs, perennial non-legume forbs, legumes, grasses, sedges, rushes and other monocots. Mosses and lichens were treated as distinct functional groups. The DCA was based on the biomass of plant functional groups as variables and plots as cases. To reveal patterns in phytomass structure we calculated non-parametric Spearman rank correlation coefficients between plot scores on three first axes and variables from the main matrix (biomass of various functional groups) and the following additional variables, which were not used in the DCA: species number per plot, total community phytomass, litter, total biomass, vascular plant biomass, $\mathrm{LA}_{\mathrm{CW}}$ and SLA $\mathrm{CW}_{\mathrm{CW}}$

\section{RES U LTS}

\section{Phytomass structure}

The Tibetan and Caucasian alpine communities showed overlaps in their total phytomass values, except for the Tibetan grazed meadows MG which had the lowest phytomass and the Caucasian FVG which had a very high litter accumulation (Table 1). However, the phytomass structure of the alpine communities was extremely variable both between and within regions. Species number per plot in the Tibetan meadows and grazed bogs significantly exceeded that in the Caucasus (Table 1). Despite the high biomass variability and differences in floristic richness, some communities showed similar features, both in Tibet and the Caucasus (Table 1).

Litter mass in the fenced Tibetan plots (MG and FG) was similar to that in the Caucasian GHM, SB and AF. Total biomass of the fenced plots was comparable with the biomass values of the productive Caucasian communities GHM and FVG and the communities with a high abundance of cryptogams ALH and AF. When excluding cryptogams, the biomass of only the vascular plants in the MF was close to that of the SBC, ALH and AF. However, only the Caucasian AF contained the same biomass of mosses as the MF, FF and FG. In the grazed Tibetan meadows we observed significantly lower biomass values of mosses than in the other Tibetan communities, but it was significantly higher than in the Caucasian communities other than AF.

Data on the Tibetan communities per species biomass are presented in the Appendix.

\section{Community weighted traits}

Only two communities from Tibet (MF) and the Caucasus (SBC) didn't differ significantly in $\mathrm{LA}_{\mathrm{CW}}$. In the other Caucasian communities $\mathrm{LA}_{\mathrm{CW}}$ significantly exceeded that in the Tibetan meadows and fens with the highest values in the GHM and AF.

In the Caucasus SLA ${ }_{\mathrm{CW}}$ was the highest in the $\mathrm{SB}$, and decreased towards the exposed communities of the FVG and ALH (Table 1). It was also lower in the AF. In Tibet the grazed alpine fen FG showed lower SLA ${ }_{C W}$ values then the grazed meadow MG. In fenced plots SLA ${ }_{C W}$ exceeded that in grazed plots, and was close to that in the SBC and AF. SLA ${ }_{\mathrm{CW}}$ in the grazed meadow MG was similar to that in the AF.

\section{Ordination by functional groups}

The DCA distinctly showed variability of plant communities along three axes. The eigenvalue of the first axis was 0.730 , the second axis 0.312 (Fig. 2), and the third axis was 0.180 (data not shown). The first axis clearly indicated the 
position of the communities in the catena. One side of the gradient represented the Caucasian ridges with the ALH and the rather dry southwestern slopes, occupied by the FVG, while the other part covered the moist habitats of both the Caucasian and Tibetan alpine fens. The position of a plot on the first axis was mainly determined by the biomass of mosses (Spearmen $\mathrm{R}=0.587, \mathrm{p}<0.001$ ) and lichens $(\mathrm{R}=$ $-0.554, \mathrm{p}<0.001)$. The most significant correlations of this axis were observed with $\mathrm{SLA}_{\mathrm{CW}}(\mathrm{R}=0.649, \mathrm{p}<0.001)$, total phytomass $(\mathrm{R}=-0.540, \mathrm{p}<0.001)$ and litter accumulation $(\mathrm{R}=0.522, \mathrm{p}<0.001 ;$ Table 2$)$.

The second axis reflected total community phytomass with the low productive Caucasian ALH and SBC and grazed Tibetan meadows $\mathrm{MG}$ on the one side of the axis and communities with a high phytomass accumulation, such as the FVG (litter accumulation) and the alpine fens $\mathrm{AF}$ and FF, on the other. The position of plots on this axis was mostly determined by the biomass values of forbs $(\mathrm{R}=0.602, \mathrm{p}<0.001)$ and grasses $(\mathrm{R}=-0.638, \mathrm{p}<0.001)$. This axis also was correlated significantly with SLA ${ }_{C W}$, total phytomass and litter accumulation, but it was also positively linked with species number per plot $(\mathrm{R}=0.318, \mathrm{p}<0.001)$.

\section{DISCUSSION}

\section{Phytomass structure}

In both regions we observed a highly variable phytomass structure in the alpine communities.

The aboveground biomass of various alpine meadows of the Qinghai-Tibetan plateau varies from 31.8 to $255.9 \mathrm{~g} / \mathrm{m}^{2}$ (Sun et al. 2013) and more, to $347.5 \mathrm{~g} / \mathrm{m}^{2}$ (Yang et al. 2009), and our data on Tibet fall in this range. Grazed Tibetan mea- dows and bogs had the lowest total and vascular plant biomass among communities due to permanent yak grazing.

The total biomass values in Tibetan alpine meadows that were fenced during a few years is comparable with the biomass values of the productive Caucasian FVG and GHM, but most of the MF biomass consists of mosses. Mosses are also an important component of grazed meadows, but when grazing was excluded, their biomass significantly increased. Thus, under the humid conditions of the Eastern Qinghai-Tibetan plateau complete cessation of yak grazing should lead to an increase of moss abundance and possible subsequent waterlogging at least in sites where shrubs initially are not very abundant. An increase in mosses was also observed after cessation of reindeer grazing in high arctic communities (van der Val \& Brooker 2004) and in hemiarctic snowbeds (Olofsson et al. 2002).

\section{Patterns of the functional structure of the alpine communities}

The use of the abundance of plant functional groups in the DCA ordination allowed us to distinctly separate plant communities in consistence with their position along the catena within regions. The functional groups, which strongest determined the sequence of plots along the first ordination axis, were cryptogams, where lichens indicated the snow free ridges (ALH, Caucasus), and mosses the wet habitats (alpine fens, Caucasus and Tibet). Tibetan alpine meadows occupied an intermediate position between alpine fens and Caucasian snowbeds. Though these meadows occupy open slopes and have a rather long growing season, the monsoon climate, with most of the precipitation falling in summer, probably provides sufficient water availability

Table 1. Aboveground phytomass structure of alpine communities in Tibet and the Caucasus (Mean \pm St.E). MG - grazed alpine meadow, MF - fenced alpine meadow, FG - grazed alpine bog, FF - fenced alpine bog, ALH - alpine lichen heath, FVG - Festuca varia grassland, GHM - Geranium-Hedysarum meadow, SBC - snow bed community, AF - alpine fen. Different letters shows significantly different values (Mann-Whitney U-test)

\begin{tabular}{|c|c|c|c|c|c|c|c|c|c|}
\hline \multirow[t]{2}{*}{ Community } & \multicolumn{4}{|c|}{ Tibet } & \multicolumn{5}{|c|}{ Caucasus } \\
\hline & MG & MF & FG & FF & ALH & FVG & GHM & SBC & AF \\
\hline Number of plots & 57 & 10 & 20 & 10 & 104 & 92 & 92 & 92 & 39 \\
\hline Number of species per $0.0625 \mathrm{~m}^{2}$ & $29 \pm 0.5^{\mathrm{a}}$ & $30 \pm 1.8^{\mathrm{a}}$ & $16 \pm 0.9^{\mathrm{b}}$ & $12 \pm 0.7^{c}$ & $13 \pm 0.3^{c}$ & $7 \pm 0.5^{\mathrm{d}}$ & $11 \pm 0.3^{c}$ & $9 \pm 0.2^{\mathrm{e}}$ & $7 \pm 0.4^{\mathrm{d}}$ \\
\hline Shrubs, $g \cdot \mathrm{m}^{-2}$ & $13.4 \pm 2.6$ & $26.3 \pm 8.9$ & $0.1 \pm 0.1$ & 0 & 0 & 0 & 0 & 0 & 0 \\
\hline Dwarf shrubs, $g$. & 0 & 0 & 0 & 0 & $31.9 \pm 6.0$ & 0 & 0 & 0 & 0 \\
\hline Annuals, $\mathrm{g} \cdot \mathrm{m}^{-2}$ & $0.8 \pm 0.2$ & $0.3 \pm 0.1$ & $0.9 \pm 0.6$ & $0.03 \pm 0.02$ & $0.5 \pm 0.1$ & $0.03 \pm 0.02$ & $0.06 \pm 0.03$ & 0 & 0 \\
\hline Perennial non-legume forbs, $\mathrm{g} \cdot \mathrm{m}^{-2}$ & $61.4 \pm 3.1$ & $82.4 \pm 7.1$ & $15.2 \pm 2.8$ & $30.1 \pm 4.0$ & $54.2 \pm 2.6$ & $31.1 \pm 4.0$ & $159 \pm 12$ & $120 \pm 5$ & $58.7 \pm 9.1$ \\
\hline Legumes, $g \cdot \mathrm{m}^{-2}$ & $4.5 \pm 0.9$ & $6.7 \pm 1.7$ & 0 & 0 & $10.1 \pm 1.7$ & $0.01 \pm 0.01$ & $47.8 \pm 6.8$ & 0 & 0 \\
\hline Grasses, $\mathrm{g} \cdot \mathrm{m}^{-2}$ & $13.3 \pm 1.4$ & $25.2 \pm 6.2$ & $4.3 \pm 1.2$ & $3.4 \pm 1.7$ & $28.5 \pm 1.5$ & $245 \pm 15$ & $95.7 \pm 6.9$ & $29.9 \pm 2.9$ & $28.8 \pm 5.0$ \\
\hline Sedges, $g \cdot \mathrm{m}^{-2}$ & $18.6 \pm 1.5$ & $22.8 \pm 6.9$ & $46.3 \pm 2.8$ & $66.3 \pm 5.4$ & $18.9 \pm 2.0$ & $6.3 \pm 1.5$ & $5.9 \pm 1.0$ & $3.7 \pm 0.7$ & $90.5 \pm 9.7$ \\
\hline Rushes, $\mathrm{g} \cdot \mathrm{m}^{-2}$ & $0.2 \pm 0.1$ & $0.2 \pm 0.2$ & $5.6 \pm 1.6$ & $0.6 \pm 0.3$ & $1.0 \pm 0.2$ & $0.1 \pm 0.1$ & $0.4 \pm 0.2$ & $0.01 \pm 0.01$ & $5.0 \pm 1.5$ \\
\hline Other monocots, & $1.2 \pm 0.2$ & $1.1 \pm 0.3$ & 0 & 0 & $0.4 \pm 0.1$ & $0.02 \pm 0.01$ & $0.01 \pm 0.01$ & $0.02 \pm 0.01$ & 0 \\
\hline Vascular plants, $\mathrm{g} \cdot \mathrm{m}^{-2}$ & $114 \pm 5^{a}$ & $165 \pm 14^{\mathrm{b}}$ & $72 \pm 5^{c}$ & $100 \pm 6^{a}$ & $145 \pm 8^{\mathrm{b}}$ & $282 \pm 14^{\mathrm{d}}$ & $309 \pm 11^{\mathrm{e}}$ & $154 \pm 6^{\mathrm{b}}$ & $183 \pm 15^{\mathrm{b}}$ \\
\hline Mosses, $\mathrm{g} \cdot \mathrm{m}^{-2}$ & $9.1 \pm 0.7^{\mathrm{a}}$ & $160 \pm 29^{\mathrm{b}}$ & $117 \pm 26^{\mathrm{b}}$ & $367 \pm 24^{c}$ & $2.9 \pm 1.4^{\mathrm{d}}$ & $4.1 \pm 1.0^{\mathrm{e}}$ & $0.6 \pm 0.4^{\mathrm{f}}$ & $2.7 \pm 0.9^{\mathrm{de}}$ & $277 \pm 43^{\mathrm{bc}}$ \\
\hline Lichens, $g \cdot \mathrm{m}^{-2}$ & $0.6 \pm 0.1^{\mathrm{a}}$ & $24.3 \pm 9.7^{c}$ & $0.6 \pm 0.4^{\mathrm{b}}$ & $4.2 \pm 1.2^{c}$ & $349 \pm 19^{\mathrm{d}}$ & $19.2 \pm 4.7^{\mathrm{ac}}$ & $2.3 \pm 0.9^{\mathrm{b}}$ & $1.2 \pm 0.4^{\mathrm{b}}$ & 0 \\
\hline Total biomass, $g$ & $123 \pm 5^{a}$ & $349 \pm 28^{\mathrm{b}}$ & $190 \pm 28^{\mathrm{ac}}$ & $472 \pm 23^{d}$ & $497 \pm 18^{\mathrm{d}}$ & $306 \pm 14^{\mathrm{b}}$ & $312 \pm 11^{\mathrm{b}}$ & $158 \pm 6^{c}$ & $460 \pm 38^{\text {bd }}$ \\
\hline Litter, $g \cdot \mathrm{m}^{-2}$ & $5.7 \pm 0.3^{\mathrm{a}}$ & $194 \pm 20^{\mathrm{bc}}$ & $59 \pm 8^{\mathrm{d}}$ & $166 \pm 15^{\mathrm{b}}$ & $223 \pm 10^{c}$ & $832 \pm 56^{\mathrm{e}}$ & $189 \pm 14^{\mathrm{b}}$ & $160 \pm 18^{\mathrm{b}}$ & $162 \pm 13^{b}$ \\
\hline Total phytomass, $\mathrm{g} \cdot \mathrm{m}^{-2}$ & $129 \pm 5^{a}$ & $543 \pm 32^{\mathrm{b}}$ & $249 \pm 33^{c}$ & $637 \pm 22^{\mathrm{de}}$ & $720 \pm 21^{\mathrm{d}}$ & $1140 \pm 60^{\mathrm{f}}$ & $501 \pm 19^{b}$ & $317 \pm 21^{\mathrm{c}}$ & $622 \pm 34^{\text {be }}$ \\
\hline $\begin{array}{l}\text { Community biomass weighted } \\
\text { leaf area, } \mathrm{cm}^{2}\end{array}$ & $1.8 \pm 0.1^{\mathrm{a}}$ & $2.3 \pm 0.2^{\mathrm{b}}$ & $1.8 \pm 0.1^{\mathrm{a}}$ & $3.2 \pm 0.2^{c}$ & $3.2 \pm 0.1^{\mathrm{c}}$ & $3.3 \pm 0.1^{\mathrm{c}}$ & $11.9 \pm 0.5^{\mathrm{d}}$ & $2.3 \pm 0.1^{\mathrm{b}}$ & $10.4 \pm 0.6^{\mathrm{e}}$ \\
\hline $\begin{array}{l}\text { Community biomass weighed } \\
\text { specific leaf area, } \mathrm{cm}^{2} \cdot \mathrm{g}^{-1}\end{array}$ & $183 \pm 2^{a}$ & $186 \pm 3^{\mathrm{ac}}$ & $173 \pm 4^{\mathrm{b}}$ & $186 \pm 3^{\mathrm{ac}}$ & $140 \pm 1^{\mathrm{d}}$ & $93 \pm 4^{e}$ & $170 \pm 2^{\mathrm{b}}$ & $192 \pm 2^{c}$ & $184 \pm 3^{a}$ \\
\hline
\end{tabular}




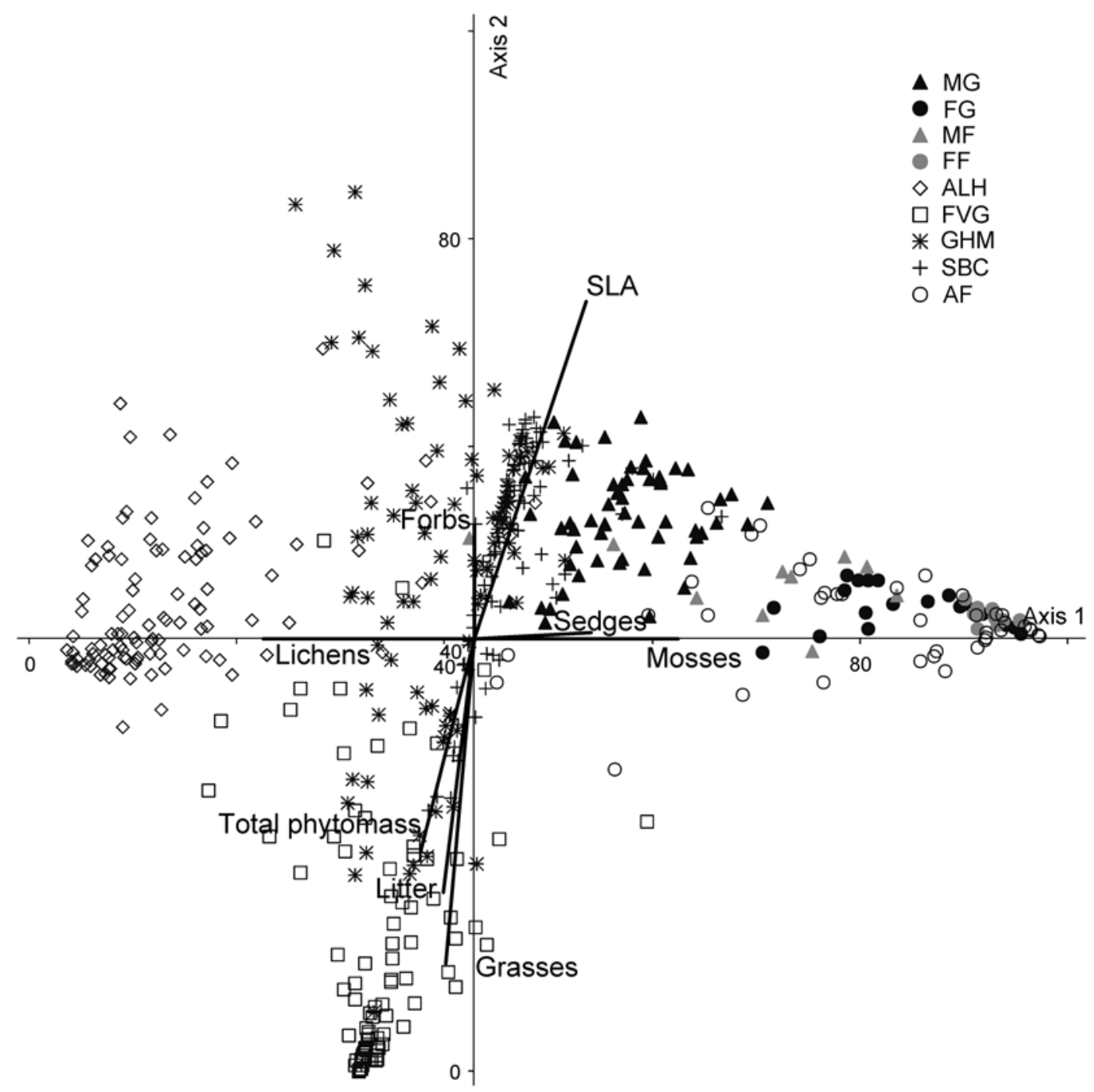

Figure 2 Results of Detrended Correspondence Analysis (DCA), based on plant functional groups biomass: mosses, lichens, annuals, perennial non-legume forbs, legumes, shrubs, dwarf shrubs, grasses, sedges, rushes, and other monocots. Arrows show correlations of axes with primary and additional variables. Tibetan communities: MG - grazed meadows, FG - grazed fens, MF - fenced meadows, FF - fenced fens. Caucasian communities: ALH - alpine lichen heath, FVG - Festuca varia grasslands, GHM Geranium-Hedysarum meadows, SBC - alpine snow beds, AF - alpine fen. SLA - specific leaf area

for good growth of bryophytes. Short-term fencing favors better moss growth both in fens and meadows.

The second axis separated communities dominated by forbs and grasses with the FVG, of which the biomass is mostly formed by the narrow-leaved grasses Festuca varia and Nardus stricta, on the one side of the axis and the GHM, in which perennial forbs with large leaves prevail, on the

Table 2. Spearmen rank correlation coefficients between the three first DCA ordination axes scores and community characteristics ( $\mathrm{n}=516$ plots). ${ }^{*}-\mathrm{p}<$ $0.05 ; * *-p<0.01 ; * * *-p<0.001$

\begin{tabular}{|l|c|c|c|}
\hline Community characteristics & Axis 1 & Axis 2 & Axis 3 \\
\hline Total phytomass & $-0.540^{* * *}$ & $-0.538^{* * *}$ & $0.100^{*}$ \\
\hline Total biomass & $-0.426^{* * *}$ & $-0.258^{* * *}$ & $-0.197^{* * *}$ \\
\hline Vascular plant biomass & $-0.206^{* * *}$ & $-0.080^{\text {n.s. }}$ & $0.258^{* * *}$ \\
\hline Litter & $-0.522^{* * *}$ & $-0.538^{* * *}$ & $0.254^{* * *}$ \\
\hline Species number per plot & $0.044^{\text {n.s. }}$ & $0.318^{* * *}$ & $-0.327^{* * *}$ \\
\hline Community biomass weighed leaf area & $-0.098^{*}$ & $-0.016^{\text {n.s. }}$ & $-0.006^{\text {n.s. }}$ \\
\hline Community biomass weighed specific leaf area & $0.649^{* * *}$ & $0.663^{* * *}$ & $-0.196^{* * *}$ \\
\hline
\end{tabular}

other. Prevalence of narrow-leaved grasses with a low SLA in the FVG explains the correlation of the second axis with total phytomass and litter accumulation values. In turn, in-

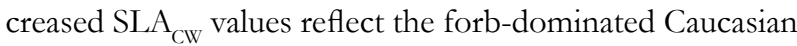
GHM, SBC and the Tibetan MG. Alpine meadows and fens of the studied Tibetan communities have comparable $\mathrm{SLA}_{\mathrm{CW}}$ values as the Caucasian SBC and GHM, where the season with permanent snow cover is long. SLA usually increases in communities with higher nutrient content and water availability (Wright et al. 2002; Pickup et al. 2005; Shidakov \& Onipchenko 2007). In well-watered pastures, where the low stature of rosette forbs and the position of their leaves close to the soil surface provide a better $\mathrm{CO}_{2}$ supply, a high SLA is beneficial for a more effective $\mathrm{CO}_{2}$ assimilation rate (Schulze et al. 2005). On the other hand, a high SLA is 
mostly associated with a higher relative growth rate (Hunt \& Cornelissen 1997; Atkin et al. 1996). This seems important both in habitats with a short growing season and in frequently disturbed communities with a permanent removal of biomass, such as heavy grazing under rather wet conditions (Dobarro et al. 2013). Though grazing by ungulates in the Teberda reserve is negligible, the SBC and GHM suffer grazing by the common vole (Pitymys majori Thos.), and fast re-growth may be important for a range of species together with other adaptations to grazing tolerance, such as position of buds on the soil surface. Also $\mathrm{SLA}_{\mathrm{CW}}$ values may provide indirect evidence that the Caucasian snowbeds originate as a result of overgrazing. Indeed, the structure and total biomass of alpine snowbeds in the subarctic is strongly affected by herbivores (Virtanen 2000; Olofsson et al. 2002). The decrease of $S L A_{C W}$ towards alpine fens is mostly linked with the high abundance of Cyperaceae which have rather low SLA values.

Short-term fencing led to a slight increase of SLA ${ }_{C W}$ in the Tibetan alpine meadow and a significant increase in the alpine fen. Perennial forbs persisted in the FF and increased in abundance, while grasses had the same biomass in both the FF and FG.

It is interesting to point out, that $\mathrm{LA}_{\mathrm{CW}}$ was slightly correlated only with the first axis, and thus leaf area was not a main driver in the determination of the functional structure of the studied communities. However, $\mathrm{LA}_{\mathrm{CW}}$ in Tibetan pastures was lowest, and only in fenced plots the relative abundance of species with larger leaves increased; LA $\mathrm{CW}_{\text {in }}$ these communities did not significantly differ from that in the Caucasian SBC.

Thus, our data at least partly confirmed all our hypotheses. We revealed some similarities in the functional structure of the alpine communities of the Caucasus and Tibet, especially in communities which occupy the lower parts of the catena, e.g. the alpine bogs. While the upper parts of the catena mostly reflects climatic conditions (temperature regime and precipitation, including snow accumulation), its lower parts are characterized by specific water regimes and bring about a higher abundance of bryophytes and Cyperaceae. Grazing by ungulates benefits traits which are also typical for communities with frequent disturbances, for example as caused by the activities of small mammals.

\section{ACKNOWLEDGEMENTS}

This study is supported by grants of the Chinese Academy of Sciences Fellowships for Young International Scientists (2011Y1SA01), grant of the International Science \& Technology Cooperation Program of China № 2013DFR90670, grant of the Ministry of Science and Technology (2011BAC09B04-02-03), RFBR № 14-0400214. The data analysis and the preparation of the draft was supported by grant № 14-50-00029 "Scientific basis of the national biobank - depositary of the living systems" (branch "Plants") from Russian Science Foundation (RNF). We are grateful to Guo Haixia, Wang Jinniu and Wang Qian for their help in the field studies in China and to all the participants of expedition in the Teberda Reserve who took part in biomass sampling.

\section{LITERATURE CITED}

Atkin, O.K., B. Botman \& H. Lambers 1996. The causes of inherently slow growth in alpine plants: an analysis based on the underlying carbon economies of alpine and lowland Poa species. Functional Ecology 10: 698-707.

Chen, W., Y. Wu, N. Wu \& P. Luo 2008. Effect of snow-cover duration on plant species diversity of alpine meadows on the eastern Qinghai-Tibetan plateau. Journal of Mountain Science 5: 327-339.

Chollet, S., S. Rambal, A. Fayolle, D. Hubert, D. Foulquié \& E. Garnier 2014. Combined effects of climate, resource availability, and plant traits on biomass produced in a Mediterranean rangeland. Ecology 95: 737-748.

Cingolani, A.M., M. Cabido, D.E. Gurvich, D. Renison \& S. Díaz 2007. Filtering processes in the assembly of plant communities: are species presence and abundance driven by the same traits? Journal of Vegetation Science 18: 911-920.

Cornelissen, J.H.C., S. Lavorel, E. Garnier, S. Díaz, N. Buchmann, D.E. Gurvich, P.B. Reich, H. ter Steege, H.D. Morgan, M.G.A. van der Heijden, J.G. Pausas \& H. Poorter 2003. A handbook of protocols for standardised and easy measurement of plant functional traits worldwide. Australian Journal of Botany 51: 335-380.

Dobarro, I., C.P. Carmona \& B. Peco 2013. Dissecting the effects of simulated cattle activity on floristic composition and functional traits in Mediterranean grasslands. PLoS One 8(11): e79822. doi: 10.1371/journal.pone.0079822.

Elumeeva, T.G., V.G. Onipchenko \& Y. Wu 2015. Leaf functional traits of plants of alpine pastures at the eastern Qinghai-Tibetan plateau. Moscow University Biological Sciences Bulletin 70(1): 46-52 (in Russian). [Елумеева Т.Г., Онипченко В.Г., У Янь 2015. Функциональные признаки мистьев растений высокогорных пастбищ востока Цинхай-Тибетского нагорья // Вестник Московского университета. Сер. 16. Биомогия. № 1. С. 46-52].

Elumeeva, T.G., D.K. Tekeev, Y. Wu, Q. Wang \& V.G. Onipchenko 2014. Life-form composition of alpine plant communities at the Eastern Qinghai-Tibetan plateau. Plant Biosystems 148(5): 988-994.

Freschet, G., J.H.C. Cornelissen, R.S.P. van Logtestijn \& R. Aerts 2010. Evidence of the "plants economics spectrum" in a subarctic flora. Journal of Ecology 98: 362-373.

Garnier, E. 1992. Growth analysis of congeneric annual and perennial grass species. Journal of Ecology 80: 665-675.

Helsen, K., M. Hermy \& O. Honnay 2012. Trait but not species convergence during plant community assembly in restored semi-natural grasslands. Oikos 121: 2121-2130.

Huck, C., C. Körner \& E. Hiltbrunner 2013. Plant species dominance shifts across erosion edge-meadow transects in the Swiss Alps. Oecologia 171: 693-703.

Hunt, R. \& J.H.C. Cornelissen 1997. Components of relative growth rate and their interrelations in 59 temperate plant species. New Phytologist 135: 395-417.

Olofsson, J., J. Moen \& L. Oksanen 2002. Effects of herbivory on competition intensity in two arctic-alpine tundra communities with different productivity. Oikos 96: 265-272.

Onipchenko, V.G. 2004. Geography, geology, climate and the communities studied. In: Alpine ecosystems in the Northwest Caucasus (V.G. Onipchenko, ed.), pp 1-7, Kluwer, Dordrecht.

Onipchenko, V.G., A.A. Shulakov, A.S. Zernov, T.G. Elumeeva, Y. Wu, Q. Wang \& M.J.A. Werger 2014. Contrasting floristic richness of alpine plant communities on the Eastern Qinghai-Tibetan plateau. Botanica Pacifica 3(1): 33-37.

Onipchenko, V.G., A.S. Zernov, \& F.M. Vorob’eva 2011. Vascular plants of Teberda Reserve (annotated list of species), 2nd ed. Flora and fauna of natural reserves, 99A, MAKS Press, Moscow. 144 р. [Онипченко В.Г., Зернов А.С., Воробьева Ф.М. Сосудистые растения Теб̆ердинского заповедника (аннотированный список видов). ИзА. 2-е, испр. и Аоп. М.: МАКС Пресс, 2001. 144 с.].

Peel, M.C., B.L. Finlayson \& T.A. McMahon 2007. Updated world map of the Köppen-Geiger climate classification. Hydrology and Earth Systems Sciences 11: 1633-1644. 
Pickup M., M. Westoby \& A. Basden 2005. Dry mass costs of deploying leaf area in relation to leaf size. Functional Ecology 19:88-97.

Pipenbaher, N., N.W.H. Mason \& S. Ŝkornik 2014. Floristic and functional diversity of meadows from two neighboring biogeographic regions. Annales, Series Historia Naturalis 24(1): 49-60.

Pérez-Harguindeguy, N., S. Díaz, E. Garnier, S. Lavorel, H. Poorter, P. Jaureguiberry, M.S. Bret-Harte, W.K. Cornwell, J.M. Craine, D.E. Gurvich, C. Urcelay, E.J. Veneklaas, P.B. Reich, L. Poorter, I.J. Wright, P. Ray, L. Enrico, J.G. Pausas, A.C. de Vos, N. Buchmann, G. Funes, F. Quétier, J.G. Hodgson, K. Thompson, H.D. Morgan, H. ter Steege, M.G.A. van der Heijden, L. Sack, B. Blonder, P. Poschlod, M.V. Vaieretti, G. Conti, A.C. Staver, S. Aquino \& J.H.C. Cornelissen 2013. New handbook for standardised measurements of plant functional traits worldwide. Australian Journal of Botany 61: 167-234.

Schulze, E.-D., E. Beck \& K. Müller-Hohenstain 2005. Plant Ecology. Springer, Berlin-Heidelberg, 702 pp.

Shidakov, I.I. \& V.G. Onipchenko 2007. Comparative analysis of alpine plant leaf traits in the Teberda reserve. Bulletin of the Moscow Society of Naturalists 112(4):42-50 (in Russian with English summary) [Шилаков И.И., Онипченко В.Г. 2007. Сравнение параметров Аистового аппарата растений альпийского пояса Тебердинского заповедника // Бюмлетень Московского общества испытателей природы, отАел биомогический. Т. 112, № 4. С. 42-50].

Soudzilovskaia, N.A., T.G. Elumeeva, V.G. Onipchenko, I.I. Shidakov, F.S. Salpagarova, A.B. Khubiev, D.K. Tekeev \& J.H.C. Cor- nelissen 2013. Functional traits predict relationship between plant abundance dynamic and long-term climate warming. Proceedings of the National Academy of Sciences of the United States of America 110: 18180-18184.

Sun, J., G.W. Cheng \& W.P. Li 2013. Meta-analysis of relationships between environmental factors and aboveground biomass in the alpine grassland on the Tibetan Plateau. Biogeosciences 10: $1707-1715$.

van der Val, R. \& R.W. Brooker 2004. Mosses mediate grazers impacts on grass abundance in arctic ecosystems. Functional Ecology 18: 77-86.

Virtanen, R. 2000. Effects of grazing on above-ground biomass on a mountain snowbed, NW Finland. Oikos 90: 295-300.

Wright, I.J., P.B. Reich, J.H.C. Cornelissen, D.S. Falster, P.K. Groom, K. Hikosaka, W. Lee, C.H. Lusk, Ü. Niinemets, J. Oleksyn, N. Osada, H. Poorter, D.I. Warton \& M. Westoby 2005. Modulation of leaf economic trait relationships by climate. Global Ecology and Biogeography 14: 411-421.

Wright, I.J., M. Westoby \& P.B. Reich 2002. Convergence towards higher leaf mass per area in dry and nutrient poor habitats has different consequences for leaf life span. Journal of Ecology 90: 534-543.

Wu, Z.Y. \& P.H. Raven (eds.) 1994-2014. Flora of China. Science Press, Beijing; Missouri Botanical Garden Press, St. Louis.

Yang, Y., J. Fang, C. Ji \& W. Han 2009. Above- and belowground allocation in Tibetan grasslands. Journal of Vegetation Science 20: $177-184$

Appendix. Biomass of vascular plant species in Tibetan plant communities (Mean \pm StError, $\mathrm{g} \cdot \mathrm{m}^{-2}$ ). $\mathrm{n}-$ number of samples (plots for biomass). MG - grazed alpine meadow, MF - fenced alpine meadow, FG - grazed alpine bog, FF fenced alpine bog

\begin{tabular}{|c|c|c|c|c|}
\hline \multirow[t]{2}{*}{ Species } & \multicolumn{4}{|l|}{ Community } \\
\hline & MG & MF & FG & FF \\
\hline Agrostis hugoniana Rendle & $0.236 \pm 0.113$ & $0.140 \pm 0.105$ & & \\
\hline Allium rude J.M. Xu & $0.063 \pm 0.026$ & $0.129 \pm 0.129$ & & \\
\hline Allium sikekimense Baker & $0.726 \pm 0.105$ & $0.984 \pm 0.245$ & & \\
\hline Anaphalis nepalensis (Spreng.) Hand.-Mazz. & $0.719 \pm 0.273$ & $0.923 \pm 0.601$ & & \\
\hline Androsace brachystegia Hand.-Mazz. & $0.542 \pm 0.464$ & $3.48 \pm 1.23$ & $0.953 \pm 0.538$ & \\
\hline Androsace mariae Kanitz & $0.182 \pm 0.142$ & & & \\
\hline Anemone demissa J.D. Hooker \& Thomson & $0.189 \pm 0.119$ & $0.064 \pm 0.064$ & & \\
\hline Anemone obtusiloba D. Don & $3.11 \pm 0.49$ & $2.80 \pm 1.14$ & & \\
\hline Anemone trullifolia Hook f. et Thoms. & $2.05 \pm 0.42$ & $2.78 \pm 1.23$ & $0.078 \pm 0.069$ & \\
\hline Angelica apaensis R.H. Shan \& C.Q. Yuan & $0.020 \pm 0.011$ & & & \\
\hline Aster souliei Franchet & $0.557 \pm 0.204$ & $1.46 \pm 1.41$ & & \\
\hline Astragalus sp. & $1.94 \pm 0.76$ & & & \\
\hline Astragalus skythropos Bunge & $0.076 \pm 0.053$ & $0.995 \pm 0.974$ & & \\
\hline Arenaria trichophylla C.Y. Wu ex L.H. Zhou & $0.109 \pm 0.042$ & $0.009 \pm 0.006$ & $0.083 \pm 0.042$ & $0.031 \pm 0.026$ \\
\hline Callianthemum farreri W.W. Smith & $0.103 \pm 0.061$ & & & \\
\hline Caltha scaposa J.D. Hooker \& Thompson & $0.221 \pm 0.165$ & $0.890 \pm 0.391$ & $0.312 \pm 0.217$ & $0.270 \pm 0.140$ \\
\hline Carex atrofusca Schkuhr subsp. minor (Boott) T. Koyama & $0.865 \pm 0.391$ & $0.449 \pm 0.264$ & & \\
\hline Carex atrofuscoides K.T. Fu & & & & $0.142 \pm 0.142$ \\
\hline Carex cruenta Nees & $0.646 \pm 0.279$ & $8.35 \pm 5.39$ & & \\
\hline Carex moorcroftii Falconer ex Boott & & & $4.64 \pm 1.32$ & $2.95 \pm 2.31$ \\
\hline Carex muliensis Hand.-Mazz. & & & $8.32 \pm 2.13$ & $23.9 \pm 4.3$ \\
\hline Carex parva Nees & & & $7.11 \pm 2.63$ & $1.41 \pm 0.69$ \\
\hline Cerastium pusillum Seringe & $0.083 \pm 0.059$ & & & \\
\hline Chamaesium paradoxum $\mathrm{H}$. Wolff & $0.211 \pm 0.188$ & & & \\
\hline Cremanthodium discoideum Maxim. & $0.035 \pm 0.033$ & & $0.574 \pm 0.308$ & $0.008 \pm 0.008$ \\
\hline Cremanthodium lineare Maxim. & $0.272 \pm 0.172$ & $1.57 \pm 0.47$ & $3.27 \pm 0.69$ & $9.71 \pm 2.35$ \\
\hline Cremanthodium potaninii C. Winkler & & $0.104 \pm 0.104$ & & \\
\hline Deschampsia caespitosa (L.) P. Beauv. subsp. orientalis Hultén & $5.40 \pm 1.03$ & $13.0 \pm 4.5$ & $2.22 \pm 1.25$ & $1.47 \pm 0.90$ \\
\hline Deyeuxia flavens Keng & $0.721 \pm 0.173$ & $0.380 \pm 0.228$ & $0.089 \pm 0.082$ & $0.263 \pm 0.263$ \\
\hline Draba eriopoda Turcz. & $0.014 \pm 0.014$ & & & \\
\hline Elymus schrenkianus (Fischer et C.A. Mey.) Tzvel. & $0.166 \pm 0.014$ & & & \\
\hline
\end{tabular}




\begin{tabular}{|c|c|c|c|c|}
\hline \multicolumn{5}{|l|}{ Appendix. Continued } \\
\hline \multirow{2}{*}{ Species } & \multicolumn{4}{|l|}{ Community } \\
\hline & MG & MF & FG & FF \\
\hline Euphorbia sp. & $1.61 \pm 0.19$ & $5.84 \pm 1.23$ & & \\
\hline Euphrasia regelii Wettstein & $0.050 \pm 0.023$ & $0.010 \pm 0.007$ & & \\
\hline Festuca ovina $\mathrm{L}$. & $5.05 \pm 0.56$ & $10.4 \pm 2.6$ & $0.686 \pm 0.218$ & $0.819 \pm 0.390$ \\
\hline Fritillaria unibracteata P.K. Hsiao \& K.C. Hsia & $0.002 \pm 0.002$ & $0.009 \pm 0.009$ & & \\
\hline Galium sp. & $0.069 \pm 0.069$ & & & \\
\hline Gentiana crassuloides Bureau \& Franchet & $0.160 \pm 0.036$ & $0.188 \pm 0.112$ & $0.002 \pm 0.002$ & \\
\hline Gentiana georgei Diels & $0.451 \pm 0.432$ & & & \\
\hline Gentiana hexaphylla Maxim. ex Kusnezov & $2.43 \pm 0.45$ & $1.75 \pm 0.60$ & & \\
\hline Gentiana sinoornata I.B. Balfour & $0.016 \pm 0.012$ & $6.55 \pm 3.34$ & $2.30 \pm 0.65$ & $8.32 \pm 2.46$ \\
\hline Gentiana squarrosa Ledeb. & $0.349 \pm 0.155$ & $0.059 \pm 0.059$ & $0.022 \pm 0.009$ & $0.032 \pm 0.022$ \\
\hline Gentiana striata Maxim. & $0.042 \pm 0.019$ & & & \\
\hline Geranium pylzowianum Maxim. & $0.075 \pm 0.032$ & $0.144 \pm 0.120$ & & \\
\hline Hedysarum algidum L.Z. Shue & $0.023 \pm 0.017$ & & & \\
\hline Hedysarum sikekimense Benth. ex Baker & $2.43 \pm 0.60$ & $5.67 \pm 1.82$ & & \\
\hline Juncus sikkkimensis J.D. Hooker & & $0.170 \pm 0.170$ & $0.138 \pm 0.138$ & \\
\hline Juncus thompsonii Buchen. & $0.204 \pm 0.089$ & & $5.50 \pm 1.56$ & $0.550 \pm 0.343$ \\
\hline Kobresia bumilis (C.A. Mey.) Serg. & $13.8 \pm 1.3$ & $8.35 \pm 3.39$ & $21.4 \pm 3.2$ & $20.6 \pm 3.5$ \\
\hline Kobresia kansuensis Kük. & $0.739 \pm 0.315$ & $3.38 \pm 2.10$ & $4.21 \pm 1.36$ & $17.0 \pm 4.8$ \\
\hline Kobresia vidua (Boott ex C.B. Clarke) Kük. & $2.24 \pm 0.32$ & $2.23 \pm 0.70$ & $0.66 \pm 0.61$ & $0.037 \pm 0.037$ \\
\hline Lancea tibetica J.D. Hooker \& Thomson & $1.78 \pm 0.32$ & $0.47 \pm 0.17$ & & \\
\hline Leontopodium franchetii Beauv. & $3.70 \pm 0.86$ & $3.88 \pm 1.39$ & $3.78 \pm 1.07$ & $6.52 \pm 1.08$ \\
\hline Lomatogoniopsis alpina T.N. Ho \& S.W. Liu & $0.215 \pm 0.057$ & & $0.023 \pm 0.023$ & \\
\hline Lonicera rupicola Hook. f. et Thoms. & $0.004 \pm 0.004$ & & & \\
\hline Oxytropis kansuensis Bunge & $0.020 \pm 0.020$ & & & \\
\hline Pedicularis davidii Franch. & $0.026 \pm 0.023$ & & & \\
\hline Pedicularis lasiophrys Maxim. & $0.055 \pm 0.031$ & $0.241 \pm 0.226$ & & \\
\hline Pedicularis longiflora J. Rudolph & $0.615 \pm 0.377$ & $0.005 \pm 0.005$ & $0.693 \pm 0.241$ & \\
\hline Pedicularis oederi Vahl & $0.140 \pm 0.050$ & $2.23 \pm 1.12$ & & \\
\hline Pedicularis plicata Maxim. & $0.017 \pm 0.009$ & $0.148 \pm 0.148$ & & \\
\hline Pedicularis roylei Maxim. & $0.001 \pm 0.001$ & $0.011 \pm 0.011$ & & \\
\hline Pleurospermum wilsonii $\mathrm{H}$. de Boissieu & $0.163 \pm 0.063$ & $2.33 \pm 1.66$ & & \\
\hline Poa albertii Regel & $0.031 \pm 0.031$ & & & \\
\hline Poa calliopsis Litv. & & & $1.24 \pm 0.42$ & \\
\hline Poa sp. & $0.024 \pm 0.024$ & & & \\
\hline Poa versicolor Besser & $0.658 \pm 0.151$ & $0.108 \pm 0.045$ & $0.082 \pm 0.067$ & $0.030 \pm 0.030$ \\
\hline Polygonatum qinghaiense Z.L. Wu et Y.C. Yang & $0.461 \pm 0.103$ & & & \\
\hline Polygonum macrophyllum D. Don & $5.01 \pm 0.77$ & $17.4 \pm 3.4$ & $1.08 \pm 0.25$ & $3.54 \pm 0.78$ \\
\hline Polygonum viviparum $\mathrm{L}$. & $0.346 \pm 0.117$ & $0.049 \pm 0.038$ & $0.050 \pm 0.026$ & $0.154 \pm 0.148$ \\
\hline Potentilla fruticosa $\mathrm{L}$. & $13.3 \pm 2.6$ & $24.4 \pm 8.8$ & $0.056 \pm 0.056$ & \\
\hline Potentilla saundersiana Royle & $2.84 \pm 0.39$ & $0.560 \pm 0.271$ & & \\
\hline Primula stenocaly $x$ Maxim. & $0.048 \pm 0.033$ & & & \\
\hline Ptilagrostis concinna (J.D. Hooker) Roshevitz & $0.190 \pm 0.089$ & & & \\
\hline Ranunculus nephelogenes Edgeworth & & & $0.332 \pm 0.152$ & $0.007 \pm 0.007$ \\
\hline Ranunculus tanguticus (Maxim.) Ovcz. & $0.463 \pm 0.122$ & $0.064 \pm 0.035$ & $0.133 \pm 0.058$ & $0.005 \pm 0.005$ \\
\hline Rheum pumilum Maxim. & $0.138 \pm 0.073$ & & & \\
\hline Salix sp. & $0.027 \pm 0.020$ & $0.956 \pm 0.539$ & & \\
\hline Sanicula hacquetioides Franch. & $1.68 \pm 0.36$ & $1.21 \pm 0.47$ & & \\
\hline Saussurea erubescens Lipsch. & $0.578 \pm 0.222$ & $2.22 \pm 0.79$ & $0.103 \pm 0.052$ & $0.956 \pm 0.700$ \\
\hline Saussurea graminea Dunn & $2.64 \pm 0.62$ & $0.011 \pm 0.011$ & & \\
\hline Saussurea leiocarpa Hand.-Mazz. & $0.166 \pm 0.099$ & $0.049 \pm 0.034$ & & \\
\hline Saussurea leontodontoides (DC.) Sch.Bip. & $3.77 \pm 1.30$ & $0.247 \pm 0.247$ & $0.033 \pm 0.033$ & \\
\hline Saussurea stella Maxim. & & & $0.894 \pm 0.618$ & \\
\hline Saussurea tatsienensis Franch. & $2.87 \pm 0.76$ & $2.21 \pm 0.95$ & & $0.216 \pm 0.216$ \\
\hline Saxifraga birculus $\mathrm{L}$. & $0.117 \pm 0.038$ & & $0.651 \pm 0.249$ & $0.037 \pm 0.035$ \\
\hline Saxifraga tangutica Engler & & $0.027 \pm 0.018$ & $0.011 \pm 0.009$ & $0.003 \pm 0.003$ \\
\hline Sedum sp. & $0.001 \pm 0.001$ & & & \\
\hline Sibbaldia procumbens L. & $9.22 \pm 1.61$ & $10.2 \pm 3.8$ & & \\
\hline Silene sp. & $0.001 \pm 0.001$ & & & \\
\hline
\end{tabular}


Elumeeva et al.

Appendix. Continued
\begin{tabular}{|l|l|l|l|l|}
\hline \multirow{2}{*}{ Species } & \multicolumn{1}{l}{ Community } & FG & FF \\
\cline { 2 - 5 } & MG & MF & \\
\hline Spiraea alpina Pallas & $0.047 \pm 0.026$ & $0.878 \pm 0.878$ & & \\
\hline Swertia wolfgangiana Gruning & & $0.438 \pm 0.438$ & & \\
\hline Tanacetum tatsienense (Bureau et Franch.) K. Bremer et Humphries & $0.310 \pm 0.092$ & $1.75 \pm 0.66$ & $0.058 \pm 0.052$ & \\
\hline Taraxacum sp. & $1.68 \pm 0.26$ & $0.138 \pm 0.111$ & & \\
\hline Thalictrum alpinum L. & $4.23 \pm 0.46$ & $3.76 \pm 1.39$ & $0.250 \pm 0.090$ & $0.046 \pm 0.030$ \\
\hline Tongoloa taeniophylla (H. de Boissieu) H. Wolff & $2.45 \pm 0.32$ & $2.82 \pm 1.32$ & $0.002 \pm 0.002$ & $0.242 \pm 0.158$ \\
\hline Trichophorum distigmaticum (Kükenthal) T.V. Egorova & $0.314 \pm 0.245$ & & & \\
\hline Trisetum spicatum (L.) Richt. & $0.788 \pm 0.217$ & $1.14 \pm 0.51$ & & $0.772 \pm 0.772$ \\
\hline Trollius farreri Stapf & $2.12 \pm 0.36$ & $1.22 \pm 0.56$ & $0.446 \pm 0.181$ & \\
\hline Trollius vaginatus Hand.-Mazz. & $0.096 \pm 0.060$ & $0.070 \pm 0.037$ & & \\
\hline Viola biflora L. var. rockiana (W. Becker) Y.S. Chen & $0.285 \pm 0.061$ & $0.062 \pm 0.053$ & & \\
\hline Boraginaceae sp. & $0.004 \pm 0.004$ & & & \\
\hline Carex sp. & & & & $0.353 \pm 0.353$ \\
\hline Asteraceae sp. & $0.816 \pm 0.245$ & & & \\
\hline
\end{tabular}

